\title{
COBRANÇA SIMULTÂNEA DE ICMS SOBRE IMPORTAÇÃO E POR SUBSTITUIÇÃO TRIBUTÁRIA CONSISTE HIPÓTESE DE BIS IN IDEM?
}

\section{Guilherme Dourado Aragão Sá Araujo}

Mestre em Direito Constitucional pela Universidade de Fortaleza. Professor do Centro Universitário Católico de Quixadá. gdourado@edu.unifor.br

\section{Resumo:}

A Constituição Federal, ao delimitar as competências e limitações ao poder de tributar, instituiu a possibilidade de incidência do Imposto sobre Operações Relativas à Circulação de Mercadorias e sobre Prestações de Serviços de Transporte Interestadual e Intermunicipal e de Comunicação (ICMS) e sobre bens e mercadorias importados do exterior (artigo 155,

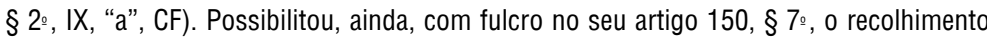
antecipado de tributo cujo fato gerador, presume-se, ocorrerá em momento posterior, mediante a substituição tributária. Por meio de investigação bibliográfica e documental, verifica-se que, não raro, surgem questionamentos quanto à possibilidade de cumulação do ICMS sobre a importação com o ICMS pela substituição tributária progressiva, ocasião em que se alega haver hipótese de bis in idem. Em análise escorreita, constata-se não haver caso de bis in idem por não existir uma dupla incidência de normas sobre um mesmo fato gerador, vez que se trata de fatos geradores distintos: primeiro a importação e depois a futura circulação da mercadoria.

\section{Palavras-chave:}

ICMS. Importação. Substituição tributária. Bis in idem.

\section{DOES SIMULTANEOUS LEVY OF ICMS ON IMPORT AND IN TAX SUBSTITUTION CONSISTS OF BIS IN IDEM HYPOTHESIS?}

\section{Abstract:}

The Federal Constitution, in defining the powers and limitations of taxation instituted the possibility of tax incidence on transactions relating to the circulation of goods and interstate and intermunicipal transportation and communication services (ICMS, in Portuguese) incidence on imported goods from abroad (art. 155, § 2, IX, "a”, CF). Enabled, also, with fulcrum in it's art. 150, $\S 7 \circ$, the advance payment of tax whose taxable event, it's assumed, will occur at a later stage, through the tax substitution. Through literature and documents research, it turns out that often questions appear about the possibility of cumulating ICMS on imports with ICMS in tax substitution, in which it's alleged to be a bis in idem hypothesis. In 
slimmer analysis, it turns out that there isn't a bis in idem hypothesis as there is no double incidence on the same taxable event, since it consists in distinct triggering events: first the importation and then the future circulation of those goods.

\section{Keywords:}

ICMS. Importation. Tax substitution. Bis in idem.

Recebido em: 18/12/2016

Aceito em: 1־/6/2018

\section{Sumário:}

1 Introdução. 2 Competência Tributária para Instituição do ICMS. 3 A Nova Face do ICMS: sua incidência na importação. 4 A Substituição Tributária Progressiva no ICMS. 5 Diferenças Entre bis in idem e Bitributação. 6 Análise da Legislação do Estado do Ceará. 7 Conclusão. 8 Referências. 


\section{INTRODUÇÃO}

Ao delimitar as competências e limitações ao poder de tributar, a Constituição Federal autorizou aos Estados e ao Distrito Federal a instituição do Imposto Sobre Operaçôes Relativas à Circulação de Mercadorias e Sobre Prestaçôes de Serviços de Transporte Interestadual e Intermunicipal e de Comunicação (ICMS).

Entre os aspectos de incidência desse tributo a Constituição, em seu artigo 155, $\$ 2$ o, IX, “a”, com redação dada pela Emenda Constitucional n. 33 de 2001, autorizou aos entes competentes a possibilidade de incidência do ICMS sobre a importaçáo de bens ou mercadorias provenientes do exterior, independentemente de se tratar de bem destinado a consumidor final ou ao ativo fixo de empresas.

Em paralelo à competência para tributar, a Constituição, no $₫ 7^{\circ}$ do seu artigo 150, dispositivo inserido pela Emenda Constitucional n. 3 de 1993, possibilita aos entes tributantes a cobrança antecipada, mediante lei, de tributo cujo fato gerador venha a ocorrer posteriormente.

Trata-se da chamada substituição tributária progressiva ou "para a frente", que legitima ao ente público presumir que o fato gerador irá ocorrer futuramente e recolher o tributo que considerar devido, resguardada a repetição de indébito no caso de o fato gerador não vir a acontecer na prática.

Ao se cumular a cobrança do ICMS sobre produtos importados com o ICMS por substituição tributária progressiva, fica o questionamento se há configuração de uma hipótese de bis in idem tributário, que, por sua vez, trata-se de uma dupla incidência tributária sobre um mesmo fato gerador provocada por normas concorrentes editadas pelo mesmo ente político.

Por meio do presente estudo busca-se verificar os critérios constitucionais e legais para a instituição do ICMS especificamente quanto à possibilidade de tributação de importações de bens e mercadorias, assim como sua compatibilidade com o instituto da substituição tributária progressiva.

Demonstra-se o que viria a ser bis in idem em matéria tributária, bem como analisa-se se há, de fato, uma dupla incidência de normas sobre o mesmo fato gerador no caso de cumulação do ICMS sobre importação com o ICMS pela substituição tributária progressiva. 


\section{COMPETÊNCIA TRIBUTÁRIA PARA INSTITUIÇÃO DO ICMS}

O poder de tributar é inerente à existência do Estado e ao exercício do poder político. É por meio da tributação que esse Estado obtém meios financeiros necessários ao custeio de suas atividades essenciais. Assim, toda e qualquer atuação estatal enseja gastos que têm, por fonte primordial de receitas, a tributação.

O surgimento do Estado Constitucional moderno e as limitaçóes ao exercício arbitrário do poder político não deixaram de exercer influência sobre o poder de tributar, que passou, de uma fase de arbitrariedade confiscatória para um exercício limitado e legitimado (ao menos em tese) pela soberania da vontade popular.

O Direito Tributário é, em si e por si, um Direito eminentemente constitucional, que, por sua vez, mantém guarnição no Estado Democrático de Direito, justificador e balizador dos direitos e garantias constitucionalmente previstos. O conceito de democracia voltado especificamente para o Direito Tributário enseja uma aceitação popular dos tributos instituídos, como uma forma de se observar a concordância do titular do poder político com seu efetivo exercício por seus representantes.

É dessa necessária representação da vontade popular que surgiu, nas colônias britânicas na América, a expressão "no taxation without representation" , símbolo da gênese do princípio da legalidade em matéria tributária e da posição do Legislativo como porta-voz do povo no exercício do poder político.

Da tendência atual a uma participação proativa do chamado Estado Social surge a necessidade de se ampliar a arrecadação como forma de garantir o sustento dessas novas atividades, o que se dá, primordialmente, por meio dos tributos (HOLMES; SUNSTEIN, 2000).

\footnotetext{
1 "Não há tributação sem representação", uma invocação da necessidade de aceitação popular no âmbito tributário, originada quando a Grä-Bretanha tentou majorar os impostos sobre as 13 colônias na América, um dos estopins da Independência Americana.
} 
Esse anseio em conferir ao Estado maiores competências de atuação acaba por elevar os gastos fiscais, acarretando um necessário aumento de sua arrecadação. Cumpre assinalar os limites impostos quanto ao exercício do poder de tributar, quer expressos ou implícitos, no interesse de conter o avanço estatal sobre os direitos fundamentais dos contribuintes. Na síntese de Aliomar Baleeiro (2006, p. 2):

Nos países de Constituição rígida e de controle judiciário das leis e atos administrativos, os princípios que a Ciência das Finanças apurou em sua compósita formação política, moral, econômica ou técnica são integrados em regras estáveis e eficazes. Funcionam como limitaçóes ao poder de tributar. $[\ldots]$

O sistema tributário movimenta-se sob complexa aparelhagem de freios e amortecedores, que limitam os excessos acaso detrimentosos à economia e à preservação do regime e dos direitos individuais.

Os limites à atuação estatal são de ordem prioritariamente legal e constitucional. O início da relação jurídico-tributária dá-se quando a Constituição Federal delega à União, aos Estados, ao Distrito Federal e aos municípios a competência para, mediante lei ordinária (em regra, podendo ser por meio de lei complementar em casos expressos), instituir tributos (SCHOUERI, 2012).

Em atenção ao princípio da legalidade, os entes tributantes podem instituir os tributos cuja competência lhes forem atribuídas. Em outro diapasão, a Constituição submete à lei complementar a determinação das normas gerais do sistema tributário nacional, a serem observadas pelos entes federativos no exercício de sua competência legislativa, podendo, desde que expressamente autorizados, prescrever de forma diversa da norma geral (MACHADO, 2012).

Dessa forma, a Lei Fundamental, em seu artigo 155, II, prescreve aos Estados e ao Distrito Federal a competência para, mediante lei ordinária, instituírem o Imposto Sobre Operaçóes Relativas à Circulação de Mercadorias e Sobre Prestaçóes de Serviços de Transporte Interestadual e Intermunicipal e de Comunicação (ICMS). $\mathrm{O}$ inciso XII do $\$ 2^{\circ}$ do mencionado artigo prevê a necessidade de lei complementar para regular determinadas matérias, em âmbito geral, para este imposto. 
À lei complementar n. 87 de 1996 (Lei Kandir) coube regular as normas gerais a serem respeitadas pelos Estados e pelo Distrito Federal no exercício de sua competência tributária, além, por óbvio, do Código Tributário Nacional, recepcionado pela Constituiçáo como lei complementar. No Estado do Ceará, a lei estadual n. 12.670 de 1996 instituiu o ICMS e prescreveu, entre as mais diversas matérias, duas que se destacam por apresentarem relevantes controvérsias judiciais: a hipótese de incidência do ICMS sobre importação e o regime de substituição tributária sobre fatos geradores futuros, ambos objetos de estudo a seguir.

\section{A NOVA FACE DO ICMS: Sua Incidência na Importação}

Objeto de intermináveis controvérsias doutrinárias quanto à terminologia adequada, entre as quais se destacam as obras de Alfredo Augusto Becker (2010) e Paulo de Barros Carvalho (2013), predomina a hipótese de incidência para designar a norma juridicizante que abstratamente atribui a um fato comum da vida uma consequência jurídica. É uma previsão legal que descreve um fato comum e a ele atribui significância jurídica. Na doutrina de Geraldo Ataliba (2000, p. 58):

\footnotetext{
A h.i. [hipótese de incidência] é primeiramente a descrição legal de um fato: é a formulação hipotética, prévia e genérica, contida na lei, de um fato (é o espelho do fato, a imagem conceitual do fato; é o seu desenho).

É, portanto, mero conceito, necessariamente abstrato. É formulado pelo legislador fazendo abstração de qualquer fato concreto. Por isso é mera "previsão legal" (a lei é, por definição, abstrata, impessoal e geral).
}

Essa abstração é, portanto, a hipótese que, se materializada, fará incidir a norma instituidora do tributo. Percebe-se que a determinação da hipótese de incidência se dá no plano legal e dentro dos limites impostos no âmbito constitucional. Dessa forma, a Constituição prescreve as orientaçôes gerais quanto à instituição dos tributos de competência dos entes federativos, orientaçôes que devem, por óbvio, ser observadas pela lei que vier a instituir o tributo. A conclusão desse raciocínio é que não cabe à lei alterar ou ampliar os preceitos constitucionais, sob risco de se transpassar os limites da competência tributária (CARRAZZA, 2009). 
No âmbito do ICMS, a Constituição Federal e a LC 87/96 traçaram quatro diretrizes como critérios materiais passíveis de incidência. Em suma, o constituinte autoriza ao legislador ordinário instituir as seguintes hipóteses de incidência: 1) Operação relativa à circulação de mercadorias; 2) Serviços de transporte interestadual e intermunicipal; 3) Serviços de comunicação e 4) Entrada de bem ou mercadoria importada do exterior. É válido ressaltar que parte da doutrina traz uma outra categoria, referente ao ICMS sobre energia elétrica.

Na primeira situação a lei definirá como hipótese de incidência do ICMS a operação relativa à circulação de mercadorias em que haja uma alteração da sua titularidade jurídica. Não é o mero trânsito geográfico que determina esse ato de promover a circulaçáo, e sim uma mudança da titularidade. É por esse motivo que o ICMS náo incide sobre o mero deslocamento de mercadorias entre estabelecimentos de uma mesma pessoa sem que haja alteração de sua titularidade. Nesse sentido é o artigo 155, II da CF e o artigo 2º, I da LC 87/96.

Ainda, em virtude de se utilizar o termo "mercadoria", não estão os Estados ou o Distrito Federal autorizados a tributar a operaçáo de circulação de qualquer objeto que náo se amolde ao conceito de mercadoria. Considera a doutrina e a jurisprudência como mercadorias aqueles bens destinados ao comércio. Dessa forma, conforme conclui Hugo de Brito Machado (2012, p. 381), "os bens destinados ao consumo ou ao ativo fixo do estabelecimento não são mercadorias. Tampouco o serão mercadorias os bens importados por quem com eles não vai comercializar". Bens destinados ao consumo próprio, evidentemente, não serão comercializados, assim como os bens destinados ao ativo fixo de empresas. Dessa forma, somente aquelas mercadorias que se encontrem na situação específica de comercializáveis poderão sofrer a incidência deste imposto.

No segundo e no terceiro caso há a incidência do ICMS sobre serviços não compreendidos pela competência tributária dos municípios (Imposto Sobre Serviços de Qualquer Natureza, ISS). Tributa-se a prestação de serviços de transporte interestadual e intermunicipal e de comunicação, conforme artigo 155, II da CF e artigo $2^{\circ}$, II e III da LC 87/96, ressalvada a possibilidade de cobrança cumulada de ICMS e ISS nas prestaçóes de serviços que incluam a entrega de mercadoria, desde que expressamente previsto nos termos da LC 116/03. 
A quarta hipótese, prevista no artigo $155, \$ 2^{\circ}$, IX, "a” da CF, com redação dada pela Emenda à Constituiçáo n. 33 de 2001, determina a incidência do ICMS sobre a importação de bem ou mercadoria proveniente do exterior, independentemente de ser produto destinado ao ativo fixo ou ao consumidor final. No texto da Lei Fundamental resta prescrito:

Art. 155. compete aos Estados e ao Distrito Federal instituir impostos sobre:

II - operaçôes relativas à circulação de mercadorias e sobre prestaçóes de serviços de transporte interestadual e intermunicipal e de comunicação, ainda que as operaçôes e as prestaçôes se iniciem no exterior;

$\$ 2$ o imposto previsto no inciso II atenderá ao seguinte:

$[\ldots]$

IX - incidirá também:

a) sobre a entrada de bem ou mercadoria importados do exterior por pessoa física ou jurídica, ainda que não seja contribuinte habitual do imposto, qualquer que seja a sua finalidade, assim como sobre o serviço prestado no exterior, cabendo o imposto ao Estado onde estiver situado o domićlío ou o estabelecimento do destinatário da mercadoria, bem ou serviço;

Com a redação atual, abre-se um critério material sui generis para o ICMS. Enquanto a regra geral é que o tributo incida sobre a operação de circulação de mercadorias comercializáveis (não destinadas ao consumidor final ou ao ativo fixo), há, nesse caso, a possibilidade de se tributar a mera entrada de produto ou mercadoria proveniente do exterior. Irrelevante é questionar se o bem importado será destinado à comercialização, ao consumidor final ou ao ativo fixo. Tributar-se-á a operação igualmente. Aponta Roque Antonio Carrazza (2009, p. 83) que, ao "prevalecer esta nova redação, terá agora que pagar ICMS a pessoa física que vier a importar bens para uso próprio, ainda que sem caráter de habitualidade e sem exercer o comércio". 
A EC 33/2001 contrariou a jurisprudência e a doutrina dominante, que considerava intributável a importação de bens feita por consumidor final não destinada ao comércio. Justamente por ter alterado de forma substancial um dos critérios materiais de incidência do ICMS, a doutrina majoritária tece críticas a essa incidência. Hugo de Brito Machado (2012) e Roque Antonio Carrazza (2009) endossam as críticas à desarrazoada tributação do ICMS sobre importação ao consumidor final. Apesar, no entanto, da absoluta pertinência do posicionamento doutrinário, é fato que a incidência de ICMS sobre bens importados está assegurada pela Constituição, enquanto esta permanecer com a atual redação.

Seguindo a alteração constitucional ocorrida em 2001, a já mencionada LC 87/96 foi alterada pela LC 114/2002 de modo a compatibilizar-se com o novo regime de incidência do ICMS sobre importações, passando a dispor que o tributo incide "sobre a entrada de mercadoria ou bem importados do exterior, por pessoa física ou jurídica, ainda que não seja contribuinte habitual do imposto, qualquer que seja a sua finalidade" (artigo $2^{\circ}, \$ 1^{\circ}$, I da LC 87/96).

Ora, presentes estão, portanto, as autorizaçôes constitucionais (competência tributária) e os termos da Lei Complementar (normas gerais) para que os Estados e o Distrito Federal possam instituir, por meio de lei, as hipóteses de incidência do ICMS em seus territórios (MATTOS, 2006). Dentro dos limites supraexpostos, estes entes detêm competência para proceder ao recolhimento do ICMS sobre a importação de bens e mercadorias que ingressem do estrangeiro.

\section{A SUBSTITUIÇÃO TRIBUTÁRIA PROGRESSIVA NO ICMS}

Ao instituir a hipótese de incidência do ICMS, nos termos expostos alhures, a norma deverá dispor sobre a chamada regra matriz de incidência tributária. Paulo de Barros Carvalho (2013) cunhou esta expressão para designar os elementos essenciais que a norma de incidência deve prever para a identificação da ocorrência do fato gerador. Somente preenchidos todos os cinco critérios expostos é que se pode considerar originada a obrigação tributária correspondente. 
Em brevíssima síntese, são os critérios material (matéria tributável sujeita à incidência), temporal (momento de ocorrência do fato gerador), espacial (onde ocorreu o fato gerador, o que também determina o sujeito ativo), pessoal (sujeitos ativo e passivo da relação) e quantitativo (base de cálculo e alíquotas). Uma vez preenchidos os cinco critérios, surge a relação jurídica que vincula sujeitos ativo e passivo e cujo objeto é o pagamento do tributo.

O instituto da substituição cinge-se à sujeição passiva da obrigação tributária. Podem ser sujeitos passivos desta obrigação o contribuinte, que é aquele que pratica o fato gerador (aquele que faz surgir a obrigação) ou o responsável, aquele cujo dever decorre de expressa previsão em lei (artigo 121 do Código Tributário Nacional - CTN). Conforme Alfredo Augusto Becker (2010, p. 592), na substituição, o fato gerador (o qual denomina fato-signo presuntivo) é praticado por um indivíduo e o dever de adimplir a obrigação tributária dele correspondente é destinado a outro indivíduo:

O fenômeno da substituição opera-se no momento político em que o legislador cria a regra jurídica. E a substituição que ocorre neste momento consiste na escolha pelo legislador de qualquer outro indivíduo em substituição daquele determinado indivíduo de cuja renda ou capital a hipótese de incidência fato-signo presuntivo.

A doutrina tece uma classificação entre diferentes formas de responsabilidade: a responsabilidade por transferência e a por substituição. Diz-se responsabilidade por transferência a situação na qual, no momento do surgimento da obrigação tributária, o dever de pagar recai sobre um sujeito passivo e, posteriormente, esse dever é transferido a outro sujeito passivo (responsável por transferência). Na responsabilidade por substituição, no exato momento em que ocorre o fato gerador surge, para o substituto, o dever de pagar o tributo. A obrigação, neste caso, ocorre concomitantemente à prática do fato gerador.

A responsabilidade por substituição subdivide-se, ainda, em regressiva (ou "para trás") e progressiva (ou "para a frente") e tem por critério de classificação a posição do substituído na cadeia produtiva. Assim, é "para trás" quando o substituído encontra-se em momento anterior ao substituto. Dessa forma, o fato gerador é praticado pelo substituído (em momento anterior) e será pago pelo substituto 
em momento posterior. Há, portanto, um diferimento do pagamento do tributo, que será concentrado em um único sujeito em momento posterior à ocorrência do fato gerador.

A responsabilidade tributária por substituição "para a frente" ocorre quando o substituído ocupa uma posição posterior na cadeia produtiva. Há, nesse caso, não um diferimento da obrigação de pagar, mas sua antecipação. O substituto encontra-se em momento anterior na cadeia produtiva e deverá recolher o tributo referente aos fatos geradores antes que estes tenham ocorrido. A doutrina tece fartas críticas a essa forma de substituição tributária por concentrar em um único sujeito passivo, antes da própria ocorrência do fato gerador, a responsabilidade pelo pagamento dos tributos relativos aos fatos geradores que o Fisco presume que iráo ocorrer naquela cadeia produtiva (MANEIRA, 2003). Essa forma de substituição tributária foi inserida na Constituição por meio da Emenda Constitucional n. 3 de 1993, que, entre outras disposiçóes, fez incluir o $\$ 7^{\circ}$ ao artigo 150 da CF, in verbis:

Art. 150. [...]

$\$ 7 .^{\circ}$ A lei poderá atribuir a sujeito passivo de obrigação tributária a condição de responsável pelo pagamento de imposto ou contribuição, cujo fato gerador deva ocorrer posteriormente, assegurada a imediata e preferencial restituição da quantia paga, caso não se realize o fato gerador presumido.

Institucionalizou-se a prática que consiste na possibilidade de se cobrar um tributo antes da prática do fato gerador. Tem sede a figura do "fato gerador presumido", um instituto que possibilita à administração presumir que o fato gerador irá ocorrer, bem como proceder ao recolhimento do tributo de forma antecipada, garantida a restituição caso o fato gerador não venha a ocorrer. Os entes tributantes dispóem, portanto, da possibilidade de realizar o recolhimento do tributo com fulcro na presunção relativa da superveniente ocorrência do fato gerador.

\section{DIFERENÇAS ENTRE BIS IN IDEM E BITRIBUTAÇÃO}

A dupla incidência no âmbito tributário engloba os conceitos de bis in idem e bitributação. Ambos os casos são situaçóes em que há a incidência de mais de uma norma sobre um mesmo caso concreto. Sabendo-se que a incidência das normas 
em matéria tributária se dá nos deslindes dos cinco critérios da regra-matriz de incidência tributária, a dupla incidência de normas sobre um caso concreto presume a prévia existência de duas ou mais regras que guardem entre si uma relação de identidade quanto ao fato gerador.

Dessa forma, bis in idem e bitributação afiguram-se como casos de dupla incidência em matéria tributária. Este é o primeiro requisito de verificação dos fenômenos, de forma que, se não há uma dupla incidência, por certo não há de se falar em bis in idem ou bitributação.

Uma vez identificado o ponto nodal que une os conceitos em debate, deve-se partir para a verificação dos pontos que os diferenciam. Nesse aspecto, tem-se que bis in idem é a dupla incidência de normas provenientes de um mesmo ente federativo, enquanto na bitributação ocorre uma dupla incidência de normas oriundas de entes diversos. Este é o segundo requisito. Aponta Regina Helena Costa (2009, p. 50):

\begin{abstract}
A bitributação significa a possibilidade de um mesmo fato jurídico ser tributado por mais de uma pessoa. Diante de nosso sistema tributário, tal prática é vedada, pois cada situação fática somente pode ser tributada por uma única pessoa política, [...] Inviável, portanto, que haja mais de uma pessoa política autorizada a exigir tributo sobre o mesmo fato jurídico.
\end{abstract}

Já o bis in idem é ideia distinta, traduzida na situaçáo de o mesmo fato jurídico ser tributado mais de uma vez pela mesma pessoa política, sendo permitido pelo sistema pátrio desde que expressamente autorizado pela Constituição [...]

Dessa forma, para ocorrência de bitributação deve haver uma dupla incidência sobre um mesmo fato gerador e essa dupla incidência deve ser provocada por normas provenientes de entes distintos. Para verificação de bis in idem, deve haver uma dupla incidência sobre um mesmo fato gerador, e essa dupla incidência deve ser provocada por normas provenientes do mesmo ente tributante.

Muito se questiona se a cumulação do ICMS sobre importação com o ICMS pela substituição tributária seria um caso de bis in idem, uma vez que, no Estado do Ceará, ambos serão cobrados no mesmo momento, desde que se enquadrem nas duas hipóteses de incidência. 
Em uma análise superficial verifica-se que está presente o segundo critério de verificação (a norma é proveniente do mesmo ente tributante), entretanto, em um estudo escorreito, verifica-se que não há a dupla incidência sobre um mesmo fato gerador, primeiro dos requisitos. Ocorre que, como exposto anteriormente, ambas as figuras tratam de fatos geradores absolutamente distintos.

O ICMS sobre importação tem por fato gerador a importação de bem ou mercadorias, enquanto o ICMS pela substituição tributária tem um fato gerador presumido, que ainda irá ocorrer. Ora, no primeiro caso o fato gerador está visível e identificável de plano, enquanto, no segundo, há uma mera expectativa de que venha a ocorrer, e essa mera expectativa autoriza o Fisco a fazer o lançamento do tributo.

Resta evidente, portanto, que esta cobrança não configura hipótese de bis in idem tributário, vez que está ausente o requisito da dupla incidência. Por se tratar de fatos geradores absolutamente distintos (a importaçáo e os fatos geradores presumidos), desfigura-se a necessária dupla incidência normativa. Assim, embora as hipóteses de incidência questionadas sejam provenientes do mesmo ente político, não há uma identidade concorrencial quanto aos seus fatos geradores, o que seria critério primordial para a existência de bis in idem.

\section{ANÁLISE DA LEGISLAÇÃO DO ESTADO DO CEARÁ}

Personagem sempre questionada nas lides que se assentam sobre a exigência do ICMS sobre importação cumulado com o ICMS sobre substituição tributária, a legislação do Estado do Ceará prescreve as hipóteses de incidência dos dois casos supramencionados, sempre com base nas limitaçóes constitucionais e na sua competência tributária.

Não raro alega-se a inconstitucionalidade da cobrança do ICMS sobre importação e sobre substituição tributária por suposta afronta à competência tributária constitucional. Muitos alegam que se trata de suposto bis in idem sobre as operaçóes mercantis desenvolvidas pelos sujeitos passivos. 
A legislação do Estado do Ceará, entretanto, assenta-se em absoluta consonância com os limites constitucionais de sua competência. O ICMS, conforme exposto anteriormente, tem diversas hipóteses de incidência, entre as quais se destacam, para o presente estudo, a operação de circulação de mercadorias e a importação de bens ou mercadorias do exterior. Vejamos, pois, a matéria constitucional aplicável:

Art. 155. compete aos Estados e ao Distrito Federal instituir impostos sobre:

$[\ldots]$

II - operaçôes relativas à circulação de mercadorias e sobre prestaçôes de serviços de transporte interestadual e intermunicipal e de comunicaçáo, ainda que as operaçôes e as prestaçóes se iniciem no exterior;

$\$ 2$ o imposto previsto no inciso II atenderá ao seguinte:

IX - incidirá também:

a) sobre a entrada de bem ou mercadoria importados do exterior por pessoa física ou jurídica, ainda que não seja contribuinte habitual do imposto, qualquer que seja a sua finalidade, assim como sobre o serviço prestado no exterior, cabendo o imposto ao Estado onde estiver situado o domićlíio ou o estabelecimento do destinatário da mercadoria, bem ou serviço;

Verifica-se no inciso II do artigo 155, da CF, que há incidência do ICMS sobre a operação de circulação de mercadorias. Nesse caso a circulação, com mudança na titularidade do bem, é que determina, no caso concreto, a ocorrência do fato gerador dessa hipótese de incidência. Assim, aquele que, no exercício de sua atividade comercial, vier a fazer circular juridicamente determinada mercadoria estará a praticar o fato gerador do ICMS.

Ocorre que, para fins de facilitar a fiscalização e a arrecadação, em respeito ao princípio da praticidade, a Constituição Federal, em seu artigo 150, $\$ 7$, instituiu a substituição tributária progressiva, ou "para a frente", já mencionada no presente 
estudo em momento oportuno, e que consiste na possibilidade de cobrança antecipada do tributo cujo fato gerador ocorrerá futuramente. Este instituto, que visa à maior eficiência na fiscalização, está previsto na Constituição, in verbis:

Art. 150. [...]

\$7. ${ }^{\circ}$ A lei poderá atribuir a sujeito passivo de obrigação tributária a condição de responsável pelo pagamento de imposto ou contribuiçấo, cujo fato gerador deva ocorrer posteriormente, assegurada a imediata e preferencial restituição da quantia paga, caso não se realize o fato gerador presumido.

Ao se cumular os dois dispositivos constitucionais, verifica-se que é possível a cobrança do ICMS sobre operaçóes de circulação de mercadorias que presumidamente irão ocorrer na cadeia produtiva, concentrando a responsabilidade pelo seu pagamento na figura do substituto tributário. Dessa forma, o substituto deverá recolher, antecipadamente, os tributos relativos aos fatos geradores que ocorrerão posteriormente. No Estado do Ceará, a Lei Estadual no 12.670 de 1996 institui o ICMS nestes termos:

Art. $2^{\circ}$ - São hipóteses de incidência do ICMS:

I - as operações relativas à circulação de mercadorias, inclusive o fornecimento de alimentação e bebidas em bares, restaurantes e estabelecimentos similares; $[\ldots]$

IV - a entrada de mercadoria ou bem importado do exterior por pessoa física ou jurídica;

V - a entrada, neste Estado, decorrente de operação interestadual, de:

a) mercadoria sujeita ao regime de pagamento antecipado do ICMS na forma que dispuser o Regulamento;

Centremo-nos na hipótese de incidência prevista no inciso $\mathrm{V}$ do dispositivo colacionado. Tem-se que seu fato gerador ocorrerá no momento em que houver a entrada no território estadual da mercadoria sujeita à substituição tributária (artigo $3^{\circ}, \mathrm{XV}$ da Lei Estadual no 12.670 de 1996), nos conformes da competência 
constitucional. Em razão da substituiçãa, a Lei Estadual determina que um terceiro vinculado ao fato gerador (mas que não o tenha praticado) será responsável pelo seu pagamento, conforme se observa a seguir:

Art. 18 -A responsabilidade pelo pagamento do ICMS na condição de substituto tributário poderá ser atribuída em relação ao ICMS incidente sobre uma ou mais operaçóes ou prestaçóes, sejam antecedentes, concomitantes ou subseqüentes, inclusive ao valor decorrente da diferença entre as alíquotas interna e interestadual, nas operaçóes e prestações interestaduais que destinem bens e serviços a consumidor final localizado neste Estado, que seja contribuinte do ICMS.

$\$ 4^{\mathrm{o}}$ - As mercadorias sujeitas ao regime de substituição tributária são aquelas relacionadas no Anexo Único desta Lei.

$\mathrm{O}$ artigo 18 da precitada lei determina o regime de substituição tributária para fins de ICMS incidente sobre operaçôes antecedentes (substituição "para trás"), concomitantes ou subsequentes (substituição "para a frente") para algumas mercadorias, elencadas em anexo à Lei, entre as quais pode-se destacar, a título de exemplo, os gêneros alimentícios, a gasolina automotiva e alguns produtos hortifrutícolas.

Ora, em síntese, no caso da hipótese de incidência relativa à circulação de mercadorias em virtude da substituição tributária, considera-se ocorrido seu fato gerador no momento da entrada desta mercadoria no território do Estado do Ceará (artigo 2ª, V, Lei Estadual n. 12.670 de 1996). Embora se possa considerar certa atecnia do legislador ao considerar a ocorrência do fato gerador na substituição progressiva, vez que, na prática, o fato gerador ocorrerá posteriormente (fato gerador presumido), não há o menor indício de inconstitucionalidade nas disposiçóes em comento.

Dessa forma, ao se fazer ingressar no Estado do Ceará mercadoria sujeita ao regime de substituição tributária, há o dever de recolher o tributo em substituição aos contribuintes dos fatos geradores que presumidamente ocorrerão, resguardada a imediata restituição no caso de sua não ocorrência (artigo 150, $\$ 7^{\circ}$, CF c/c artigo 
22 Lei Estadual no 12.670 de 1996). Por conta da substituição progressiva, surge uma obrigação tributária no momento em que a mercadoria ingressa no território. Este é o primeiro fato gerador do caso em análise.

Não há de se confundir a hipótese de incidência previamente relatada com a incidência do ICMS sobre importação. Nesse caso, há respeito a outra hipótese de incidência tributária e, consequentemente, um fato gerador distinto. Esta hipótese de incidência do ICMS está expressamente prevista no supracolacionado artigo 155, $\$ 2$ o, IX, “a”. A Lei Estadual n. 12.670 de 1996 traz a hipótese de incidência e o momento do fato gerador do ICMS sobre importaçáo em seu artigo $2^{\circ}$, IV e artigo $3^{\circ}$ :

Art. $2^{\circ}$ - São hipóteses de incidência do ICMS:

I - as operaçôes relativas à circulação de mercadorias, inclusive o fornecimento de alimentaçáo e bebidas em bares, restaurantes e estabelecimentos similares;

$[\ldots]$

IV - a entrada de mercadoria ou bem importado do exterior por pessoa física ou jurídica;

Art. $3^{\circ}$ - Considera-se ocorrido o fato gerador do ICMS no momento:

VI - do desembaraço aduaneiro de mercadorias ou bens importados do exterior;

É o caso de mercadoria proveniente do exterior que ingressa no território do ente federativo. Percebe-se que, quando a mercadoria foi importada e passou pelo devido trâmite na aduana, houve a ocorrência deste fato gerador em questáo, que, nos termos do CTN, é causa necessária e suficiente ao surgimento da obrigação tributária principal, qual seja, o dever de pagar o tributo devido (artigo 114, CTN). Ocorrido o fato gerador, surge a respectiva obrigaçáo tributária, que deverá ser quitada pelo sujeito passivo quando de sua cobrança. É este o segundo fato gerador do caso em análise.

Em atinência a todo o exposto, é perceptível que as hipóteses de incidência supra- descritas são absolutamente distintas. Em um primeiro aspecto, surge o dever de pagar o tributo com base nos fatos geradores presumidos que serão praticados 
pelos substituídos e cujo recolhimento deverá ser realizado antecipadamente (artigo 155, II, c/c artigo150, $\$ 7$ o , CF). Em um segundo aspecto, emerge o dever de pagar o tributo com base no fato gerador da importaçáo de bem ou mercadoria proveniente do estrangeiro (artigo 155, $\$ 2^{\circ}$ o, IX, “a”, CF).

Ao se congregar estas conclusôes ao conceito de bis in idem tributário, verifica-se que não há sua configuração em virtude da ausência de um de seus requisitos fundamentais: a dupla incidência sobre um mesmo fato gerador. Como os fatos geradores são distintos e vinculados a hipóteses de incidência distintas, não há que se falar em hipótese bis in idem.

Apesar de os tributos serem cobrados no mesmo momento (a entrada no território do ente), esse critério temporal é apenas um dos cinco critérios que sagram a regra-matriz de incidência tributária, e, portanto, é insuficiente à configuração do bis in idem, que exige uma absoluta identidade. Ocorrem duas incidências normativas sobre fatos geradores distintos: uma sobre a importaçáo da mercadoria e outra sobre os fatos geradores que serão praticados posteriormente em virtude da responsabilidade por substituição progressiva.

\section{CONCLUSÃO}

Em atinência ao que restou evidenciado após as explanaçôes anteriores, verifica-se que a incidência do ICMS sobre a importação é assegurada pela Constituição Federal em seu artigo 155, $\$$ 20, IX, “a”, com redação dada pela Emenda Constitucional n. 33 de 2001. Igualmente constitucional é a possibilidade de cobrança antecipada do tributo cujo fato gerador ainda náo ocorreu, com fulcro no instituto da substituição tributária progressiva, embora seja, no âmbito doutrinário, plenamente criticável.

Por meio da Emenda Constitucional n. 3 de 1993, fez-se inserir o $\$ 7^{\circ}$ ao artigo $150 \mathrm{da}$ CF, segundo o qual é lícito aos entes tributantes procederem ao recolhimento do tributo cujo fato gerador presumidamente ocorrerá em momento posterior, assegurada a restituição imediata em caso de sua não ocorrência. 
Em legítimo uso dos preceitos constitucionais expostos, os entes tributantes podem instituir, por meio de lei, a incidência do ICMS sobre a importação de bens e mercadorias provenientes do exterior, cujo fato gerador é o próprio ingresso no território do ente tributante, bem como a incidência do ICMS pela substituição tributária progressiva em relação aos fatos geradores que irão ocorrer em momento posterior, mas cujo recolhimento pode ser antecipado por expressa autorização constitucional.

A cumulação destes institutos pode confundir o intérprete do Direito que se fizer de análise meramente superficial. Não raro questiona-se um suposto bis in idem quando da cobrança do ICMS sobre importação cumulado com o ICMS por substituição tributária.

Em análise escorreita, porém, percebe-se que não se configura o caso de dupla incidência em virtude de existirem fatos geradores absolutamente distintos e independentes. Por um lado, o fato gerador é a importação de bem ou mercadoria. Neste caso, o fato gerador já ocorreu e é facilmente identificável. Por outro lado, há a presunção de que outros fatos geradores irão ocorrer naquela cadeia produtiva, e, por conta destes fatos geradores futuros, incide a substituição tributária.

Evidenciada a ocorrência de fatos geradores distintos, resta afastada a hipótese de bis in idem, estando a cobrança perfeitamente balizada pelos preceitos constitucionais da tributação.

\section{REFERÊNCIAS}

ATALIBA, Geraldo. Hipótese de incidência tributária. 6. ed. São Paulo: Malheiros, 2000.

BALEEIRO, Aliomar. Limitaçöes constitucionais ao poder de tributar. 7. ed. rev. e compl. à luz da Constituição de 1988 até a Emenda Constitucional no 10/1996. Rio de Janeiro: Forense, 2006.

BECKER, Alfredo Augusto. Teoria geral do direito tributário. 5. ed. São Paulo: Noeses, 2010. BRASIL. Código Tributário Nacional. Lei no 5.172 de 1996. Disponível em: <http://www. planalto.gov.br/ccivil_03/leis/15172.htm>. Acesso em: 10 nov. 2013.

. Constituição da República Federativa do Brasil. Brasília, DF, Senado, 1988. 
BRASIL. Lei Complementar no 87 de 1996. Dispóe sobre o imposto dos Estados e do Distrito Federal sobre operaçóes relativas à circulação de mercadorias e sobre prestaçóes de serviços de transporte interestadual e intermunicipal e de comunicação, e dá outras providências (Lei Kandir). Disponível em: <http://www.planalto.gov.br/ccivil_03/leis/lcp/lcp87.htm>. Acesso em: 10 nov. 2013.

CARRAZZA, Roque Antonio. ICMS. 13. ed. São Paulo: Malheiros, 2009.

CARVALHO, Paulo de Barros. Curso de direito tributário. 25. ed. São Paulo: Saraiva, 2013. CEARÁ. Lei no 12.670 de 1996. Dispóe acerca do Imposto sobre Operaçóes Relativas à Circulação de Mercadorias e sobre Prestações de Serviços de Transporte Interestadual e Intermunicipal e de Comunicação - ICMS - e dá outras providências. Disponível em: <http:// www.al.ce.gov.br/legislativo/legislacao5/leis96/12670.htm>. Acesso em: 12 nov. 2013.

COSTA, Regina Helena. Curso de direito tributário: Constituição e Código Tributário Nacional. São Paulo: Saraiva, 2009.

HOLMES, Stephen; SUNSTEIN, Cass R. The cost of rights: why liberty depends on taxes. Nova York: W. W. Norton \& Company, 2000.

MACHADO, Hugo de Brito. Curso de direito tributário. 33. ed. São Paulo: Malheiros, 2012. MANEIRA, Eduardo. Da substituição tributária “para a frente” no ICMS. Revista Dialética de Direito Tributário, São Paulo, n. 95, ago. 2003.

MATTOS, Aroldo Gomes de. ICMS: comentários à legislação nacional. São Paulo: Dialética, 2006.

SCHOUERI, Luís Eduardo. Direito tributário. 2. ed. São Paulo: Saraiva, 2012. 